DOI: 10.26693/jmbs06.05.016

UDC 611.9:572.512:796

Karatieieva S. Yu. ${ }^{1}$, Slobodian O. M. ${ }^{1}$, Moseychuk Yu. Yu. ${ }^{2}$, Hauriak O. D. ${ }^{2}$, Goy R. S. ${ }^{1}$

\title{
Study of Anthropomentric and Morphometric Parameters in the Training of Athletes
}

\author{
'Department of anatomy, clinical anatomy and operative surgery \\ of Bukovinian State Medical University \\ ${ }^{2}$ Department of physical culture and fundamentals of health \\ of Yuriy Fedkovych Chernivtsi National University
}

The purpose of the work was to study the patterns of development and formation of the structure of the skeletal, muscular, circulatory system under the influence of various physical activities in the dynamics, followed by the definition of correlations of the value of anthropometric and morphometric parameters in the training of athletes.

Studying of the literature data, we can conclude that modern professional sports requires loads close to maximum, and sometimes even exceeding them, the establishment of these maximum permissible loads and the study of the patterns of their development is a very urgent task.

The main problem in training athletes is adequate selection and sports affiliation. Solving the problems of selection involves the creation of a model of the athlete of this specialization, that is a certain set of characteristics that determine athletic performance. This requires anthropometric assessment, morphometric and biometric data to track physical and physiological parameters, information to assess performance and recovery in sports, modification of training regimes to prevent injuries, provide guidance on regulating the use of technologies used in professional sports, as well as to research and make recommendations for the proper collection, storage and exchange of health information.

One of important problems of modern morphology is the study of changes that occur in the body under the influence of various factors. This problem has become especially important in connection with the development of sports. High sports performance, associated with a significant load on the athlete's body, encourages scientists, doctors, coaches to search for physiological reserves of the body and search for optimal training regimes. From this point of view, the study of changes that occur in individual organs, systems and in the body as a whole, under the influence of physical activity of varying intensity and nature is relevant and of great practical importance.

Conclusion. Modern professional sports require loads that are close to the maximum, and sometimes are such or exceed them. It is the establishment of these maximum allowable loads and study the patterns of their development which is a very promising area. This will allow timely selection of athletes for a particular sport, to carry out preventive and curative measures to improve their structural and functional condition.

Keywords: athletes, anthropometry, morphometry.

Introduction. Movement, in the broadest sense of this word, is a prerequisite for the existence of any living matter. Physiologist I. M. Sechenov wrote: «All the infinite variety of external manifestations of brain activity is finally reduced to a single phenomenon "muscle activity». The meaning of this expression is that all human thoughts are realized through movements. The muscles of the upper and lower extremities play a primary role in these movements [1].

Physical culture and sports are one of important means of diverse and harmonious development. Tissues, organs and systems are closely interconnected and form a single automatic and functional whole, determining the work of the whole organism. From this point of view, the constitutional approach in medicine, the foundations of which were laid by Hippocrates [2], is important.

The purpose of the work was to study the patterns of development and formation of the structure of the skeletal, muscular, circulatory system under the influence of various physical activities in the dynamics, followed by the definition of correlations of the value of anthropometric and morphometric parameters in the training of athletes.

Main part. At the present stage of development of sports and sports science, an example of the integration of modern sciences, which is based on the similarity of the structure of the internal functioning of objects, is the general theory of training athletes. Today, the theory of training athletes, based on the methodology of integrative approaches and the possibility of related disciplines, allows to provide such a systematization of knowledge, which is functional and has no contradictions, also allows to obtain knowledge accumulated in the theory of sports training, physiology, biochemistry, morphology, psychology, etc. [3]. The direction of management and control of training of athletes, their selection and orientation, modeling 
and forecasting unite the field of knowledge that has been intensively developed in the last two decades $[4,5]$. This is due to the manifestation of the general trend and objectification of the training system of athletes, the introduction of scientific and technological progress, using the capabilities of general disciplines such as cybernetics, morphometry, system approach, operation research, finding reserves to improve the training system of athletes [6-8]. In this regard, the formation of a holistic system of knowledge requires consideration of management and control, selection and orientation, modeling and forecasting, as one of the key areas in the study of the theory of training athletes [9-11].

According to Lezhneva O. V., who has studied the body structure and central hemodynamics in athletes of different sports of the adolescence and establishing relationships between hemodynamic and somatometric parameters, it was found that among athletes of different specializations and football players most of the parameters of central hemodynamics in wrestlers were the lowest. The peculiarities of the connections of the parameters of central hemodynamics with anthropometric and somatotypological indicators in young men who are engaged and not engaged in sports, as well as separately in volleyball players, athletes, wrestlers, football players of high skill level are also proved. The author establishes the features of the percentage distribution of anthropo-somatological parameters in the models of appropriate parameters of central hemodynamics in volleyball players, wrestlers, athletes and football players and proves that football players' hemodynamic parameters were determined by circumferential, longitudinal and craniometric dimensions of the body - sagittal arch of the head, width of the lower jaw, hip and thigh girth, athletes' - girth size, thickness of skin and fat folds, width of the distal epiphysis of the shoulder, football players' - body diameter, girth and craniometric dimensions.

But in order to achieve some success in sports, in addition to the study of biometric, anthropometric indicators and the stagnation of biomechanical technologies, morphometry is important for planning promising sports achievements. The task of distinguishing the variability (in a broad sense) of the shape and size of morphological objects is one of the fundamental for many biological studies [12-17]. Until recently, in studies of this kind, «parallel» existed and two different areas were developed - quantitative analytical and figurative stagnation (in a sense, "qualitative») geometric. In the first case, the task is to use a set of linear dimensions to describe the object, using various quantitative methods to obtain a dimensional component from the total variety and, consequently, to obtain a component of the form. In the simplest case, the so-called indices are calculated for this purpose, as well as the angles between the vectors passing through certain points. Similarities in form also use the Burnaby method based on regression analysis (Thorpe, 1976), principal components methods (Atchley et al., 1981) and common principal components (Flury, 1988).

So, in the field of sports, information on muscle morphology is very valuable in diagnosis or further research, after treatment or training. Ultrasound is a tool commonly used to visualize soft tissue structures in muscle diseases and the effects of physical training. The visualization allows to quantify muscle size, beam length, and pennant angle. These morphological variables are important determinants of muscle strength and tension range. Currently, image measurements are mostly performed in two-dimensional images, with the expert choosing, apparently, the appropriate orientation and location of the ultrasonic probe. Such two-dimensional methods limit morphological measurements to one plane of the image, while the parameter of interest may not be in this plane. Morphological analysis requires a 3D approach that provides off-plane measurements using a 3D scorecard. It is known that such a three-dimensional morphological image of soft tissues is provided by magnetic resonance tomography (MRT). However, MRT is expensive and not always available. Special MRT sequences, such as tensor image diffusion, are also required to visualize muscle fibers. An economical alternative to MRT is 3D ultrasound (3DUS). The 3DUS approach provides several advantages over MRT methods, for example, it imposes less restrictions on the positioning of the subject during the examination [17].

Guido Weide developed a method for performing 3D morphological ultrasound analysis of muscles. 3DUS was built from calibrated free two-dimensional ultrasonic visualization in two-dimensional mode $B$, which are placed in a voxel array. Ultrasound (US) quantified muscle size, beam length, and angle of excision. These morphological variables are important determinants of muscle strength and the range of stress strength. The author describes the approach to determine the volume and length of beams $\mathrm{m}$. vastus lateralis and $\mathrm{m}$. gastrocnemius medialis. 3DUS promotes using 3D anatomical references. This provides a rapid and cost-effective approach to quantify 3D skeletal muscle morphology, as in sports, muscle morphometry information is very valuable in diagnosis and long-term planning after treatment or exercise [18-22].

Currently, a new approach to the comparison of forms, which combines the method of transformation lattices with specific quantitative methods - «geometric morphometry» (Bookstein, 2002; Rohlf, 2002, Marcus, 2000; Pavlinov, 2000). It is a set of algebraic methods of multidimensional eigen-analysis of the 
coordinates of labels, together describing the configuration of morphological objects. The basic ideas of geometric morphometry were formulated only in the early 80 s of the $20^{\text {th }}$ century (Kendall, 1984; Bookstein, 2002). Nowadays, a very active methodology, the mathematical apparatus of which is considered to be sufficiently developed to solve many applied problems (Bookstein, 2000, 2002), published a number of monographs, collections and review articles that give a complete picture of the theory, methods and results of geometric morphometry of applied research (Rohlf, 2002; Bookstein, 2002; Bookstein, 2000; Marcus, 2000; Dryden, Mardia, 1998; Monteiro, Reis, 1999; Costa, Cesar, 2000; Pavlinov, 2002).

Pavlinov I. Y., Mikeshina N. G., 2002, had considered the basic concepts and methods of geometric morphometry, which involved a multidimensional analysis of the coordinates of the landmark, located in accordance with certain rules on the surface of the morphological object. The purpose of this was to identify differences between morphological objects in their form. Differences between forms were measured as the distance between the corresponding points. For linear methods of multidimensional statistics, to be used to compare figures, the corresponding points were projected on the tangent plane. The Procrustean distances can be used in multidimensional analysis as well as Euclidean distances. In the second case, the figures are adapted to the standards by stretching, compressing and shifting to the complete identity of the landmark configurations. The eigenvectors of the resulting bending energy matrix are defined as a new form of variables, the main skews that give a different space to the figure with the beginning defined by the reference. The projections from the forms compared on the basic bases gave partial bases, and their covariance matrix of decomposition into eigenvectors gave relative bases similar to the main components (in particular, they are mutually orthogonal). Both partial and relative bases can be used in many multidimensional statistical analyzes as quantitative variables. The results of thin-plate spline analysis were presented graphically using a transformation grid that reflects the type, number and location of differences in the figure. The basic rules of sampling and positioning of landmarks used in metrology are considered. They make it possible to estimate the correlation between different figures, as well as between the figure and some non-figure variables (linear measurements, etc.); assess the differences between organisms in the form of morphological structure; to identify the landmarks that best match both the correlations and the differences between the forms [23, 24].

Shalaev V. A., Didenko M. N., Shalaeva T. A., compared the objectivity and efficiency of morphometric data obtained by computer morphometry, as well as measurement data performed with a screw eyepiece - micrometer MOV 1-15. As a result, there was a decrease in labor intensity, increased productivity and objectivity in morphological studies. In addition, the method significantly improves the number of studies, the speed of statistical processing and obtaining visual material, which allows you to use this method [25,26].

So, analyzing the literature of scientists, it becomes clear that highly productive athletes are extraordinary people who experience high physical and psychological stress during their professional lives. However, to date, the prognostic value and dominance of indicators of total and partial body size, morphometric and somatotypological characteristics in predicting the prospects for achieving high results in sports have not been established [27-29].

Conclusion and perspective for further research. Considering the data of the literature, we can conclude that modern professional sports require loads that are close to the maximum, and sometimes are such or exceed them. It is the establishment of these maximum allowable loads and study the patterns of their development is a very promising area. This will allow timely selection of athletes for a particular sport to carry out preventive and curative measures to improve their structural and functional condition. Also, it is planned to further study the morphometric and other characteristics of athletes in order to select for certain sports.

\section{References}

1. Zlotnicki JP, Naendrup JH, Ferrer GA, Debski RE. Basic biomechanic principles of knee instability. Curr Rev Musculoskelet Med. 2016; 9: 114-122. PMID: 27007474. PCMID: PMC4896872. doi: 10.1007/s12178-0169329-8

2. Yang LT. Study on the adult physique with the Heath-Carter anthropometric somatotype in the Han of Xi'an, China. Anatom Sci Int. 2016; 91(2): 180-187. PMID: 25940679. doi: 10.1007/s12565-015-0283-0

3. Vasylev AH, Vasyleva YA, Shkurykhyn AO. Heometrycheskaia morfometryia. Ot teoryy k praktyke [Geometric morphometry. From theory to practice]. Monohrafyia. M; 2018; 471 p. [Russian]

4. Slavitiak OI. Udoskonalennia trenuvalnoho protsesu sportsmeniv u bodibildenhu, shliakhom ratsionalnoho zastosuvannia vprav bazovoho ta formuiuchoho kharakteru $v$ mezotsyklakh pidhotovky [Improvement of the training process of athletes in bodybuilding on the basis of optimal use of basic and forming exercises in preparation mesocycles]. Abstr. PhDr. (Physical Ed\&Sport.). K; 2018. 24 p. [Ukrainian] 
5. Kostiuk TM. Mahnitno-rezonansna tomohorafiia v diahnostytsi miazovo - suhlobovoi dysfunktsii skronevo-nyzhnoshchelepnoho suhloba [Magnetic resonance imagination in the diagnosis of muscle-articular dysfunction of the temporal-mandibular joint]. Ort Stomatol. 2020; 1: 108-11. [Ukrainian]

6. Vovk YuM, Vovk OYu. Indyvidualni anatomichna minlyvist ta yikh kliniko-morfolohichne znachennia [Individual anatomical variability and its clinical and morphological value]. Kharkiv; 2019. $188 \mathrm{~s}$. [Ukrainian]

7. Stsislovskyi SV, Yedynak HA, Vasylyniuk VI. Orhanizatsiia ta metodyka rozvyvalnykh zaniat z fizychnoi kultury dlia starshoklasnykiv [Organization and methodology of developing exercises on physical culture for senior pupils]. Navch posibnyk. Kamianets-Podilskyi: Ruta; 2017. 140 s. [Ukrainian]

8. Televiak AT, Veresiuk TO, Selskyi PR. Porivnialnyi analiz strukturnykh porushen miaziv zadnikh kintsivok ta zmin biokhimichnykh pokaznykiv syrovatky krovi shchuriv pry hostrii ishemii [Comparative analysis of structural violations of the muscles of the hind limbs and changes in biochemical parameters of blood serum in rats in acute ischemia]. Visnyk naukovykh doslidzhen. 2018; 3: 114-120. [Ukrainian]. doi: 10.11603/2415-8798.2018.3.9247

9. Erkomaishvyly YV, Tryfonova NN. Sportyvnaia metrolohyia [Sports metrology]. Ucheb posob. Ekaterynburg; 2016. 112 s. [Russian]

10. Tiazhelov AA, Karpynskyi MYu, Karpynskaia ED, Honcharova LD, Klymovytskyi RV, Fyshchenko VA. Kliniko-biomekhanicheskoe obosnovanie i postroenie modeli raboty myshts, obespechivaiushchikh gorizontalnoe ravnovesie taza [Clinical and biomechanical substantiation and construction model of muscles providing horizontal pelvic equilibrium]. Travma. 2017;18(5): 13-19. [Russian]. doi: 10.22141/1608-1706.5.18.2017.114115.

11. Bianchi M, Renzini A, Adamo S, Moresi V. Coordinated Actions of Micro with other Epigenetic Factors Regulate Skeletal Muscle Development and Adaptation. Int J Mol Sci. 2017 Apr 15; 18(4): 840. PMID: 28420141. PCMID: PMC5412424. doi: 10.3390/ijms18040840

12. Constantin iN, Mann G. Sports Medicine. Harefuah. 2016; 155(6): 333-334.

13. Karkazis, K, Jennifer R, Tracking US. Professional Athletes: The Ethics of Biometric Technologies. Am J Bioethics. 2016; 17(1): 45-60. PMID: 27996918. doi: 10.1080/15265161.2016.1251633

14. Jenoure P. Sports Medicine in our four neighbour countries. Swiss Sports Exercise Med. 2016; 64(4): 8-12. doi: 10.34045/SSEM/2016/20

15. Gandolfi M, Geroin C, Picelli A, Smania N, Bartolo M. Assessment of balance disorders. Advances technologies in Rehabilitation of gati and Balance disorders. NY: Springer; 2016. 536 p. doi: 10.1007/978-3-319-72736-3

16. Hageman JR. Current Educationon Sports Medicine and an on going Commitment to Our Patients. Pediatr Ann. 2017; 46(3): 78. doi: 10.3928/19382359-20170220-01

17. Chaudhary B, Tripathy PR, Gaikwad MR. Common Trunk Arising from Ansa Cervicalis Innervating Strap Muscles along with Sternocleidomastoid: A Case Report. J Clin Diagnost Res. 2018; 12(4): AD01-AD02. doi: 10.7860/ JCDR/2018/34415.11402

18. Kipp LE. Psychosocial aspects of youth physical activity. Pediatr Exercise Sci. 2017; 29(1), 35-38. PMID: 28271811. doi: 10.1123/pes.2017-0005

19. Murugan MS, Sudha R, Bhargavan R. Clinical significance ofan unusual variation: Anomalous additional belly of the sternothyroid muscle. Sultan Qaboos Univ Med. J. 2016; 16(4): e491-e494. PMID: 28003898. PCMID: PMC5135463. doi: 10.18295/squmj.2016.16.04.015

20. Kutseryb T, Vovkanych L, Hrynkiv M, Majevska S. Peculiarities of the somatotype of athletes with different directions of the training process. J Physical Educ Sport. 2017; 17(1): 431-435. doi: 10.7752/jpes.2017.01064

21. ledynak G, Galamandjuk L, Kyselytsia O, Nakonechnyi I, Hakman J, Chopik A. Special aspects of changes in physical readiness indicators of young men with different somatotypes between 15 and 17 years of age. J Physical Educ Sport. 2017; 17(4): 2690-2696. doi: 10.7752/jpes.2017.04311

22. Kissane RW, Egginton S, Askew GN. Regional variation in the mechanical properties and fibre-type composition of the rat extensor digitorum longus muscle. Exp Physiol. 2018; 103: 111-124. 2018. PMID: 29076192. doi: 10.1113/EP086483

23. Osborne B, Cunningham JL. Legal and ethical implications of athletes' biometric data collection in professional sport. Marquette Sports Law Rev. 2017; 28(1): 37-84.

24. World Medicine Association declaration of Helsinki: Ethical principles for medical research involving human subjects. 2017. Available from: https://www.wma.net/ policies-post/wma-declaration-of-helsinki-ethical-principles-for-medical-research-involving-human-subjects

25. Storey RN, Meikle GR, Stringer MD, Woodley SJ. Proximal hamstring morphology and morphometry in men: an anatomic and MRI investigation. Scand J Med Sci Sports. 2016; 26(12): 1480-1489. PMID: 26681553. doi: $10.1111 / \mathrm{sms} .12625$

26. Wikstrom EA, Song K, Pietrosimone BG, Blackburn JT, Padua DA. Visual utilization during postural control in anterior cruciate ligament- deficient and -reconstructed patients: systematic reviews and meta-analyses. Arch Phys Med Rehabil. 2017; 98: 2052-2065. PMID: 28483655. doi: 10.1016/j.apmr.2017.04.010 
27. Som PM, Laitman JT. Embryology, variations, and innerva innervationsof the human neck muscles. Neurographics. 2017; 7(3): 215-42. doi: 10.3174/ng.3170206

28. Budzhak VV. Biometriia [Biometry]. Navch posib. Chernivtsi: Chernivetskyi natsionalnyi universytet; 2016. 272 s. [Ukrainian]

29. Aruyn AS, Zatsyorskyi VM, Prylutskyi BY. Morfometryia myshts [Morphometry muscles]. Ucheb posob. M: 1988; 61 s. [Russian]

\section{УДК 611.9:572.512:796}

\section{ВИВЧЕННЯ АНТРОПОМЕТРИЧНИХ ТА МОРФОМЕТРИЧНИХ ПАРАМЕТРІВ В ПІДГОТОВЦІ СПОРТСМЕНІВ}

\section{Каратєєва С. Ю., Слободян О. М., Мосейчук Ю. Ю., Гауряк О. Д., Гой Р. С.}

Резюме. Вивчаючи дані літератури, можна зробити висновок, що сучасний професійний спорт вимагає навантажень, близьких до максимальних, а іноді і таких, що перевищують їх, встановлення цих гранічно допустимих навантажень і вивчення закономірностей їх розвитку є вельми актуальним завданням. Основна проблема в підготовці спортсменів - правильний підбір і спортивна приналежність. Рішення задач відбору передбачає створення моделі спортсмена даної спеціалізації, тобто певного набору характеристик, що визначають спортивні результати. Для цього потрібні антропометрична оцінка, морфометричні і біометричні дані для відстеження фізичних і фрізіологічних параметрів, інформація для оцінки працездатності та відновлення в спорті, зміна режимів тренувань для запобігання травм, надання рекомендацій з регулювання використання технологій, що використовуються в професійному спорті, а також дослідження і рекомендації по правильному збору, зберіганню та обміну медичною інформацією.

Однією з важливих проблем сучасної морфології є вивчення змін, що відбуваються в організмі, під дією різних факторів. Ця проблема набула особливого значення в зв'язку з розвитком спорту. Високі спортивні показники, пов'язані зі значними навантаженнями на організм спортсмена, спонукають учених, лікарів, тренерів до пошуку фрізіологічних резервів організму, і пошуку оптимальних режимів при тренуванні. 3 цієї точки зору вивчення змін, що відбуваються в окремих органах, системах і в організмі в цілому, під дією фрізичних завантажень різної інтенсивності і характеру є актуальним, і має важливе практичне значення. Перспективний напрямок дозволить своєчасно проводити відбір спортсменів для занять конкретним видом спорту, проводити профілактичні та лікувальні заходи щодо поліпшення їх структурно-функціонального стану

Ключові слова: спортсмени, антропометрія, морфометрія.

\section{УДК 611.9:572.512:796 \\ ИЗУЧЕНИЕ АНТРОПОМЕТРИЧЕСКИХ И МОРФОМЕТРИЧЕСКИХ ПАРАМЕТРОВ В ПОДГО- TOВКЕ СПОРТСМЕНОВ}

Каратеева С. Ю., Слободян О. Н., Мосейчук Ю. Ю., Гауряк О. Д., Гой Р. С.

Резюме. Изучая данные литературы, можно сделать вывод, что современный профессиональный спорт требует нагрузок, близких к максимальным, а иногда и превышающих их, установление этих предельно допустимых нагрузок и изучение закономерностей их развития является весьма актуальной задачей. Основная проблема в подготовке спортсменов - правильный подбор и спортивная принадлежность. Решение задач отбора предполагает создание модели спортсмена данной специализации, то есть определенного набора характеристик, определяющих спортивные результаты. Для этого требуются антропометрическая оценка, морфометрические и биометрические данные для отслеживания физических и физиологических параметров, информация для оценки работоспособности и восстановления в спорте, изменение режимов тренировок для предотвращения травм, предоставление рекомендаций по регулированию использования технологий, используемых в профессиональном спорте, а также исследования и рекомендации по правильному сбору, хранению и обмену медицинской информацией.

Одной из важных проблем современной морфологии является изучение изменений, происходящих в организме, под действием различных факторов. Эта проблема приобрела особое значение в связи с развитием спорта. Высокие спортивные показатели, связанные со значительными нагрузками на организм спортсмена, побуждают ученых, врачей, тренеров к поиску физиологических резервов организма и поиска оптимальных режимов при тренировке. С этой точки зрения, изучение изменений, происходящих в отдельных органах, системах и в организме в целом, под действием фризических загрузок различной интенсивности и характера является актуальным и имеет важное практическое значение. Перспективное направление позволит своевременно проводить отбор спортсменов для занятий конкретным видом спорта, проводить профилактические и лечебные мероприятия по улучшению их структурно-функционального состояния

Ключевые слова: спортсмены, антропометрия, морфометрия. 
ORCID and contributionship:

Svitlana Yu. Karatieieva : 0000-0003-1836-8337 D,F

Oleksandr M. Slobodian 0000-0002-4402-8457 c

Yurii Yu. Moseychuk 0000-0002-2457-6552 A,E

Olena D. Hauriak 0000-0002-2354-7012 F

Roman S. Goy ${ }^{\text {B }}$

A - Work concept and design, B - Data collection and analysis,

C - Responsibility for statistical analysis, D - Writing the article,

$\mathrm{E}$ - Critical review, F - Final approval of the article

\section{CORRESPONDING AUTHOR}

\section{Svitlana Yu. Karatieieva}

Bukovinian State Medical University,

Department of anatomy, clinical anatomy and operative surgery

229/b, Ruska St. apt.35, Chernivtsi 58000, Ukraine

tel: +380662670935, e.mail Karatsveta@gmail.com

The authors of this study confirm that the research and publication of the results were not associated with any conflicts regarding commercial or financial relations, relations with organizations and/or individuals who may have been related to the study, and interrelations of coauthors of the article. 